\title{
Kekuatan Psikologis Ibu untuk Menyusui
}

\section{Women's Psychological Strengths in Breastfeeding}

\author{
Inge Wattimena, Natalia L. Susanti, Yusep Marsuyanto
}

\section{Fakultas Keperawatan Universitas Katolik Widya Mandala Surabaya}

\begin{abstract}
Abstrak
Anjuran World Health Organization (WHO) agar ibu menyusui minimal selama 6 bulan masih belum tercapai. Studi ini bertujuan untuk meneliti kekuatan psikologis ibu yang berhasil menyusui lebih dari 6 bulan. Metode penelitian kualitatif deskriptif dilakukan pada enam ibu yang diambil secara purposif dengan kriteria menyusui lebih dari 6 bulan. Hasil wawancara mendalam dianalisis dan hasilnya menunjukkan bahwa kesadaran ibu tentang keunggulan dan kekuatan spiritual dalam air susu ibu (ASI) serta dukungan, afeksi positif, sikap tangguh, tujuan terarah, dan kesejahteraan menjadi kekuatan psikologis mereka. Hasil ini dapat digunakan sebagai masukan bagi promosi kesehatan untuk ibu menyusui.
\end{abstract}

Kata kunci: Menyusui, kekuatan psikologis, keberhasilan

\section{Abstract}

The World Health Organization recommendation for six months breastfeeding is not yet achieved. This study examined the psychological strengths of six women who had successfully breastfed for more than six months. A descriptive qualitative method was used. Semistructured interviews were used and the records were analyzed. It was shown that understanding of benefits and spiritual power of breastmilk, full support, positive affection, strong attitude, directed goals, and well-being become their psychological strengths. These results could be used as inputs for health promotion for breastfeeding mother.

Key words: Breastfeeding, psychological strengths, success

\section{Pendahuluan}

Menyusui adalah proses alami bagi seorang ibu untuk menghidupi dan menyejahterakan anak pascamelahirkan. Proses menyusui yang tidak mudah memerlukan kekuatan agar dapat berhasil. ${ }^{1}$ Survei awal pada ibu yang memberikan air susu ibu (ASI) lebih dari 6 bu- lan menunjukkan beberapa pendapat.

"Sebagai ibu ya harus mau menyusui, kan tanggung jawab juga, ASI tidak boleh disia-siakan"

"Menyusui itu membanggakan saya, juga suami saya"

"Niat dan kemauan harus besar dan saya mewajibkan diri"

"Yang penting ASI supaya anak kebal terhadap sakit dan pintar"

"ASI itu alami, Tuhan beri, ya diberikan, saya bersyukur dapat menyusui"

"Ikatan batin sepertinya nyetrum gitu, kalau nyusui anak melihat saya, rasanya kepingin dekat selalu, dia meraba-raba dada saya, mainan, rasanya dia senang, saya dan anak dapat kehangatan"

"Formula kan olahan pabrik, mana bisa mengalahkan ASI"

"ASI mengurangi beban, kalau tidak ASI lalu dari mana biayanya, susu mahal"

"Ibu saya terus mengingatkan untuk tidak boleh berhenti menyusui."

Survei awal ini menggambarkan bahwa keberhasilan ibu menyusui merupakan dinamika antara diri ibu, anak, situasi, kondisi, dan intervensi.

Keberhasilan menyusui menjadi perhatian karena target program sekitar $80 \%$ para ibu menyusui minimal selama 6 bulan masih jauh dari harapan. ${ }^{2}$ Berdasarkan hasil Survei Demografi dan Kesehatan Indonesia (SDKI) tahun 1997 - 2007, pemberian ASI eksklusif mengalami

Alamat Korespondensi: Inge Wattimena, Fakultas Keperawatan Universitas Katolik Widya Mandala Surabaya, Jl. Dinoyo 48 A Surabaya,

Hp.08155133220, e-mail: suroingboyo@gmail.com 
penurunan dari $40,2 \%$ menjadi $39,5 \%$ dan $32 \%$. Angka pemberian ASI masih tergolong rendah, sementara pemasaran susu formula, sosial budaya, dan ibu bekerja tidak mendukung pemberian ASI. ${ }^{3}$

Pemahaman yang semakin jauh dari kebenaran tentu memprihatinkan karena keadaan ini menyangkut kesehatan dan kesejahteraan ibu dan anak yang selanjutnya meluas ke seluruh lingkungan kehidupan. Dalam mempromosikan kesehatan secara umum dan menyusui secara khusus perlu diteliti kekuatan-kekuatan psikologis apa yang berada di balik keberhasilannya. Kekuatan ini perlu dipahami untuk dikemukakan dalam promosi kesehatan dengan harapan agar angka keberhasilan ibu menyusui semakin meningkat demi kesejahteraan keluarga, lingkungan, dan bangsa.

\section{Metode}

Penelitian ini menggunakan metode kualitatif deskriptif yang melakukan pemahaman atas keunikan, dinamika, dan hakikat holistik kehadiran manusia. Dasar pendekatan adalah pandangan dan asumsi bahwa pengalaman manusia diperoleh melalui hasil interpretasi. Data diperoleh dari wawancara semiterstruktur yang diambil secara purposif terhadap 6 ibu menyusui lebih dari 6 bulan, mempunyai rentang umur antara $22-35$ tahun, dan variasi pendidikan dari lulusan sekolah dasar sampai sarjana. Peneliti maupun informan mempunyai keleluasaan untuk berimprovisasi dalam mengungkapkan permasalahan dari segi pandang pribadi. Wawancara direkam dan ditranskripsikan. Data diorganisasi, dikelompokkan dalam tema-tema yang menerangkan tentang kekuatan ibu dalam keberhasilan menyusui, dan dianalisis. Hasil penelitian divalidasi dengan validitas komunikatif dan diverifikasi secara triangulasi dengan informan, pakar, dan literatur terkait.

\section{Hasil}

Dalam penelitian teridentifikasi bahwa kekuatan yang menyebabkan ibu berhasil menyusui lebih dari 6 bulan adalah kesadaran diri, dukungan, afeksi positif, sikap yang kuat dan baik, tujuan yang terarah, dan kesejahteraan.

\section{Kesadaran Diri}

Ibu yang berhasil menyusui lebih dari 6 bulan mempunyai kesadaran diri untuk memaknai ASI. Ia menyadari akan kelebihan yang luar biasa dalam kandungan gizi, kekebalan, dan kedekatan yang terbentuk antara ibu dan anak. Hal-hal ini yang membanggakan dan memberi pengharapan agar anak mereka tumbuh menjadi anak yang cerdas.

"Wanita-wanita Indonesia mau memberikan ASI eksklusif yang sangat berarti bagi tumbuh kembang si bayi.” (Jk)
"Dengan menyusui, anak menjadi cerdas. Anak merupakan generasi penerus bangsa, lebih memanusiakan anak manusia." (Ca)

Ibu sadar bahwa menyusui itu tugas mulia dan kewajiban tanpa pamrih. Walaupun berhadapan dengan berbagai tugas, tetapi tugas menyusui tetap nomor satu dan tidak tergantikan. Niat adalah faktor penting.

"Yang terbaik adalah memberikan ASI selama mungkin Ibu bisa lakukan dan anak mau." (Vi)

Ibu sadar akan kekuatan spiritual yang terkandung dalam ASI, merasa menjadi perempuan sempurna, dan berpendapat bahwa tidak menyusui adalah perbuatan menyia-nyiakan pemberian Tuhan Yang Maha Esa.

"Bodoh kok mukjizat Allah disia-siakan" (Li)

"Saya bisa memberikan ASI itu, di mana saat anak saya di dekapan saya, saya merasakan sungguh Tuhan itu luar biasa." (Jk)

\section{Dukungan}

Ibu yang berhasil menyusui merasa bahwa dukungan suami maupun orang-orang sekitar menambah semangat sehingga membantu keberhasilan menyusui.

"Pada saat saya memberikan ASI pada tengah malam, kadang-kadang beliaunya juga bangun hanya untuk sekedar menemani tapi itu sangat berarti buat saya. Kalau kita dipuji setelah menyusui kemudian diperhatikan dan banyak sekali keluarnya ASI, kemudian orang sekitar memuji 'Aduh, bayinya montok sekali, ASI-nya banyak...' Uuu...kekuatan saya untuk memberikan ASI semakin bertambah." (Jk)

Berbagi sesama keluarga dan teman serta peran petugas medis berguna untuk melakukan perubahan.

"Petugas kesehatan jangan hanya ceramah saja mengenai ASI namun yang paling penting mengajarkan, membimbing, mendampingi ibu-ibu pada waktu menyusui. Selain itu petugas kesehatan perlu juga mengajarkan caranya memompa ASI, menyimpan dan memberikan ASI, serta mengatur waktu untuk menyusui bagi Ibu yang bekerja dengan penjelasan mendetail. Diusulkan pula perlu adanya call center yang memberikan pelayanan dan tempat bertanya tentang caracara menyusui yang efektif dan sebagainya sehingga tidak ada lagi ibu-ibu yang mengalami kesulitan menyusui dan semuanya minum ASI eksklusif.” (Ca)

\section{Afeksi}

Berbekal kesadaran diri dan dukungan, berkembang afeksi positif terhadap menyusui. Ibu merasa kasih sayang, bangga, serta kaya akan kenangan dan kebahagiaan karena merasa menjadi ibu sesungguhnya, meskipun ada kalanya merasa kurang nyaman dengan dirinya.

"Ibu yang beneran" (Ca)

"Kejengkelan itu akan hilang tatkala pikiran saya 
mengatakan bahwa saya harus menyusui. Melihat anak saya tumbuh kembang begitu pesat, rasa kelelahan itu akan hilang dengan sendirinya. Rasa kasih, rasa sayang semua kan saya tumpahkan kepada anak.” (Jk)

\section{Sikap}

Afeksi positif terhadap ASI membuat ibu bersikap kuat dan bajik. Ia bertekad bulat menyusui sampai 2 tahun dengan atau tanpa bekerja dan siap mental. Niat dan percaya diri berpengaruh pada keluarnya ASI.

"Mau berkorban untuk sesuatu yang dipilih, mau memahami, mau berubah, mau menyetarakan." (Vi)

"Saya pasti bisa memberikan ASI." (Jk)

"Selama saya masih bisa memberikan, mengapa tidak." (Am)

Suatu godaan yang dihadapi ibu menyusui adalah susu formula. Mereka memiliki sikap kuat dan bajik dalam mempertahankan ASI. Selain itu, dengan sikap yang kuat dan bajik, ibu mempertimbangkan hak anak.

"Jangan terlalu cepat ikut dengan iming-iming karena yang diikuti itu salah. Politik perdagangan seperti di iklan susu itu kan sebenarnya pembodohan masyarakat. Pemerintah harusnya sadar. Kita sendiri yang dari institusi pendidikan harus mau memberi informasi kepada anak didik. Susu pengganti tidak dapat menggantikan ASI." (Vi)

"Anak punya hak karena ia tidak minta dilahirkan. Ia berhak menerima sesuatu yang alami yang sudah dikodratkan oleh Allah. Mereka berhak minta sesuatu dari Ibunya. ASI itu sesuatu yang alami." (Fi)

"ASI haknya dia, hak asasi anak. Jangan tidak diberikan." (Vi)

Penderitaan dan kepentingan pribadi dikesampingkan. Kekurangnyamanan diri sehabis melahirkan dan terganggunya rutinitas tidur diatasi tanpa mengganggu usaha untuk menyusui.

"Kehebatan menyusui itu merubah pribadi seseorang, egoisnya berkurang." (Vi)

\section{Tujuan}

Dengan menyusui, ibu menolong anaknya. Sebaliknya, anak pun menolong ibu untuk merasa nyaman dan mengubah kepribadian. Selain itu, ibu jugamengajarkan kepada anak suatu prinsip hidup.

"Kalau anak itu lahir ia akan berkata 'Tolonglah saya'. Ia kan dalam keadaan lemah.” (Fi)

"Ibu itu butuh anaknya. Begitu dia menyedot, sakit di payudara langsung hilang. Jadi ada kepentingan pribadi. Anak butuh orang tua itu sebetulnya salah, yang butuh itu adalah orang tua. Menyusui merubah kepribadian ibu, dari yang cuek menjadi lebih perhatian." (Vi)

"Semakin ia menggenjot, semakin keras keluar ASInya. Ini nanti terbentuk di kehidupan. Dia mengerti bahwa dalam kehidupan harus bekerja keras, harus fight untuk melakukan yang terbaik untuk dirinya." (Fi)

Ibu mengondisikan keadaan yang positif dalam diri anak karena ASI merupakan sesuatu yang berarti bagi anak dan ibu juga menyadari bahwa melalui proses menyusui terbina rasa saling yang kuat.

"Dengan diberi ASI, bayi merasa tenang, nyaman, dan pertumbuhannya sangat besar." (Jk)

"Kalau kita memberi, kita menerima. Kita tanam padi ya tumbuh padi, tanam kebaikan pasti tumbuh kebaikan. Dia tahu kebutuhan saya dan saya juga tau kebutuhan dia." (Fi)

\section{Kesejahteraan}

Ibu yang berhasil menyusui lebih dari 6 bulan menciptakan kesejahteraan ibu dan anak. Ia menikmati anak yang sehat. Ikatan erat antara keduanya menjadi penghibur.

"Anak kita jarang sakit dan juga pertumbuhannya sangat luar biasa. Kulitnya itu cenderung lebih bersih dan montok ya." (Jk)

"Sepertinya dia bilang bahwa dia sangat mencintai saya. Dia merasakan, saya kan seperti cermin dia. Kirakira anak merasa bangga punya orang tua seperti saya, bangga diberi ASI, dielus-elus juga. Apa yang saya berikan kepada bayi, dapat ia rasakan. Ia melihat dunia gimana gitu." (Li)

Antara ibu dan anak terbentuk perasaan saling yang kuat dan kegelisahan anak terbuai dengan menyusui. Sentuhan dan pandangan mata keduanya menjadi pelipur lara.

"Mungkin kata anak, 'Kalau saya bisa nolong Ibu sekarang ini, saya akan lakukan itu, seandainya saya bisa menghibur Ibu yang lagi sedih gitu, saya akan lakukan'. Dia tau kebutuhan saya dan saya juga tau kebutuhan dia. Akhirnya, jadi saya butuh anak dan anak butuh ibu." (Li)

"Kalau dia rewel, saya susui. Bisa diam seketika." (Jk)

"Bayi kan bersentuhan dengan kita, terus menatap kita, dia pegang tangan kita, rasanya saya bilang puas, lega, dan rindu. Kita pulang kerja, rasanya kangen memeluk. Sambil bersenandung, saya ajak ngomong, dia belajar, kita mengajar." (Ca)

Ibu memancarkan kebahagiaan dalam keluarga dengan menyusui karena ia mengurangi egoismenya. Selain itu, dengan menyusui ASI perekonomian keluarga juga tertolong.

"Kehebatan menyusui itu merubah pribadi seseorang. Egoisnya berkurang. Itu baik untuk hubungan dengan keluarga, dengan suami." (Vi)

"Ada kepuasan dari segi ekonomi karena susu bayi itu sangat mahal." (Fi)

\section{Pembahasan}

Tema-tema yang dibahas berdasarkan hasil penelitian 
adalah kesadaran diri, dukungan, afeksi positif, sikap kuat dan bajik, serta kesejahteraan para ibu yang merupakan kekuatan untuk berhasil menyusui lebih dari 6 bulan. Kekuatan dan keluhuran hati nurani merupakan modal untuk mengantisipasi faktor-faktor negatif yang menyebabkan keadaan patologis, kelemahan, atau keterpurukan. Perhatian ditujukan pada faktor-faktor positif untuk membangun kompetensi sebagai modal prevensi agar tidak terjadi salah dan sakit. Dapat dikatakan bahwa dengan kompetensi positif internal secara kejiwaan dan keragaan akan tercapai apa yang diharapkan.

\section{Kesadaran Diri}

Sadar diri ibu dalam memaknai ASI berperan pada tumbuh kembang anak. ${ }^{4}$ Perkembangan anak melalui kontak fisik (kontak kulit), psikis (kontak mata), suara, dan penciuman dilakukan melalui inisiasi dini atau pengenalan puting susu segera setelah bayi lahir. Interaksi ini meningkatkan hubungan batin ibu dan anak, menimbulkan rasa aman pada bayi, yang kelak akan meningkatkan rasa percaya diri seorang anak. Ikatan batin ibu dan anak juga mengurangi kejadian penyiksaan, penelantaran, dan penolakan kehadiran anak. Dengan mendekap bayi pada saat menyusui dan mengajaknya bicara dengan penuh kasih sayang, seorang ibu sudah memenuhi kebutuhan bayi akan stimulasi dan secara tidak langsung berdampak pada pemenuhan kebutuhan psikologis ibu. Stimulasi merupakan hal yang penting dalam tumbuh kembang anak. Anak yang banyak mendapat stimulasi terarah mempunyai kemungkinan cepat berkembang ke arah positif. Secara umum dapat dikatakan bahwa ASI memenuhi semua kebutuhan dasar anak untuk tumbuh dan berkembang, baik kebutuhan fisik-biomedis (asuh), kebutuhan kasih sayang/emosi (asih), maupun kebutuhan stimulasi (asah).

Kesadaran diri untuk menjadi ibu adalah pilihan dan tanggung jawab terhadap kehadiran anak yang ia bentuk. Ia bersedia berkorban, memahami, dan mau berubah. Kewajiban menyusui tanpa pamrih merupakan bentuk dari tanggung jawab, terlepas dari penderitaan atau pengorbanan diri. Kesadaran diri yang tinggi terhadap tugas mulia seorang perempuan untuk menyusui, yang sudah timbul sebelum melahirkan, merupakan prediktor baik terhadap keberhasilan. Tidak adanya intensi untuk menyusui berbanding terbalik dengan keberhasilan. ${ }^{5}$

Intensi dimulai dengan pemusatan pikiran, penataan strategi apa yang akan dilakukan, dan perencanaan lama usaha dilakukan. Ketekunan atau niat dalam pikiran merupakan bagian dari motivasi. Dalam hal menyusui, motivasi intrinsik timbul dalam diri sebagai suatu naluri alamiah atau insting biologis. Motivasi intrinsik beroperasi bila dalam diri timbul perhatian atau minat untuk berbuat sesuatu tanpa memperhitungkan suatu imbalan dari luar. Keadaan ini memperlihatkan keinginan ibu un- tuk bersatu kembali dengan anak melalui proses menyusui. Hampir semua wanita hamil memotivasi diri untuk memberikan ASI eksklusif sejak kehamilan. ${ }^{6}$

Melindungi serta menyejahterakan anak adalah tanggung jawab seorang ibu. Kekuatan spiritualnya menyentuh inteligensi atau kemampuan menyeluruh individu untuk bertindak dengan maksud tertentu, berpikir rasional, dan menghadapi lingkungan secara efektif. ${ }^{7}$ Ia beranggapan bahwa ASI tidak biasa atau tidak dapat ditiru karena merupakan anugerah yang menyucikan kehidupan spiritual sesuai arahan Tuhan Yang Maha Esa.

\section{Dukungan}

Dukungan dari suami, keluarga, media pengetahuan, dan lingkungan sosial merupakan bantuan moral yang positif untuk menghadapi beragam tantangan sewaktu menyusui. Suami yang menemani, memerhatikan gizi, memuji derasnya ASI dan sehatnya anak, serta bangga akan kesanggupan ibu menyusui akan meningkatkan motivasi ibu. Penelitian di Padang menunjukkan bahwa lebih dari separuh informan memiliki suami yang mendukung pemberian ASI eksklusif dan ternyata dukungan suami berpengaruh terhadap pemberian ASI eksklusif. ${ }^{8}$

Ibu memerlukan pengakuan dari lingkungan sosial bahwa usahanya berhasil, suatu kebutuhan untuk dihargai. Maslow, ${ }^{7}$ mengatakan bahwa kebutuhan akan harga diri yang menunjukkan kompetensi dan pengakuan berada di atas tahap kebutuhan fisiologis, kebutuhan keamanan, serta kebutuhan akan kasih dan keterlibatan. Bowlby, ${ }^{9}$ berpendapat bahwa dukungan sosial merupakan proses dua arah antara sistem membentuk kedekatan dan sistem untuk peduli. Di dalamnya ditekankan pentingnya pemberian dukungan dan kasih untuk tumbuhnya kepercayaan serta rasa aman dan nyaman dalam relasi yang dekat.

Dukungan berupa informasi, edukasi, dan komunikasi merupakan strategi positif menuju keberhasilan. Penyuluh kesehatan diharapkan memberi informasi akurat tentang ASI dan membenarkan pemahaman yang salah tentang menyusui kepada ibu hamil. ${ }^{10}$ Media pengetahuan dan lingkungan sosial merupakan sumber informasi yang berperan dalam menambah serta mengubah pandangan dan sikap. Penerangan medis yang benar diharapkan menggugah perilaku, sikap, nilai, dan kesadaran diri. Weiss, ${ }^{7}$ mengatakan bahwa peran media pengetahuan dan lingkungan sosial terbatas pada penguatan dari preferensi yang ada alih-alih mengakibatkan perubahan.

Dukungan sosial dapat berupa dukungan emosional seperti peduli dan empati, memberi umpan balik positif untuk suatu perilaku, memberi informasi untuk menolong, serta bersedia mengorbankan waktu dan memberi bantuan. Efek positif dari dukungan sosial mendukung terbentuknya kesehatan. 
Untuk merealisasikan penularan pemahaman menyusui kepada perempuan lain, ibu menyusui sendiri menjadi sumber promosi yang paten. ${ }^{11}$ Dengan usaha ini terbentuklah suatu kebersamaan dalam cita dan rasa. Dalam kebersamaan terjadi kecenderungan untuk mengikuti tekanan sosial yang nyata atau dalam imajinasi dengan saling meniru, saling memberi saran dan sugesti untuk mengikuti saran serta fasilitas sosial. Melalui promosi ini ada pesan moral yang disampaikan dan akhirnya menyentuh harkat bangsa.

\section{Afeksi}

Berafeksi positif adalah hasil proses persepsi terhadap situasi. Keadaan menguntungkan berfungsi untuk pertahanan hidup, pembangkit energi, pembawa pesan, penguat, dan penyeimbang. ${ }^{12}$ Suatu bentuk afeksi positif adalah cinta kasih yang merupakan satu-satunya jawaban yang paling logis dan memuaskan untuk semua masalah tentang keberadaan manusia. Afeksi positif dalam menyusui mempunyai dua peran yaitu peran untuk diri dan anak. Peran untuk diri diutarakan sebagai rasa bangga dan suka menjadi ibu. Peran untuk anak diutarakan ibu sebagai rasa senang melihat tumbuh kembang anak yang baik. Peristiwa yang membahagiakan akan dikenang. Ungkapan afeksi positif yang berhubungan dengan kasih sayang merupakan prediktor signifikan pembentuk kepuasan dan kebahagiaan dalam interelasi. ${ }^{13}$ Berdasarkan perspektif evolusi, kasih sayang mempunyai properti yang membantu proses adaptasi, yang memungkinkan membentuk hubungan yang erat, dekat, dan suportif. Berdasarkan sudut pandang biologis, ikatan erat memudahkan seseorang melindungi mereka yang dekat, terutama anak.

\section{Sikap}

Sikap positif dan keyakinan tinggi meningkatkan kemampuan menyusui. ${ }^{4}$ Sikap dan keyakinan menunjukkan potensi seseorang atau dikenal dengan istilah determinasi diri. Individu yang tangguh, mampu bereaksi otentik dan murni, serta mempunyai kebenaran tentang kemantapan dan kekuatan dalam dirinya. Dengan modal ini, ia mampu membuat keputusan atau menentukan sikap berdasarkan hak otonomi. Orang yang mantap dan kuat dalam bersikap, sadar akan keterbatasan dan kelemahan dirinya, tetapi ia tetap mengandalkan keputusan yang jujur dan murni. ${ }^{14}$

Ibu menghadapi tantangan menyusui dengan persiapan mental. Dalam pikiran ibu telah disadari bahwa perlu pengorbanan untuk mendapatkan apa yang dipilihnya. Mau berkorban untuk anak yang dilahirkan menunjukkan ungkapan hati nurani yang mendalam. Lalu, yang menjadi modal untuk menghadapi beragam aspek kehidupan untuk mencapai sesuatu yang menjadi tantangan adalah niat, yakin, dan percaya diri. Dengan kekuatan ini terbentuk sikap yang memungkinkan individu melihat secara realistis keadaan diri dan lingkungan. Ia semakin yakin akan kemampuannya dan mempunyai kontrol terhadap kehidupan. Dalam batas kemampuannya, ia sanggup mengerjakan apa yang menjadi harapan, rencana, dan tantangannya. Kemampuan ibu menyusui memperlihatkan keunikannya untuk peduli secara maksimal terhadap keselamatan anaknya. ${ }^{15}$

Salah satu godaan adalah mengganti ASI dengan susu formula. Ibu yang berhasil menyusui tidak tergoda karena ia sadar bahwa mengganti ASI adalah salah. Mengerti bahwa sesuatu itu salah, menyangkut inteligensi atau kecerdasan seseorang. Ia pandai melihat situasi, mempertimbangkan positif negatifnya, melihat kemampuan diri, serta mengantisipasi bila timbul keadaan yang kurang menguntungkan. Inteligensi merupakan gambaran abstrak yang disaring dari observasi perilaku dalam bermacam-macam keadaan serta merupakan konstruksi hipotetis yang hanya dapat diduga dari tanda-tanda perilaku yang cerdas. ${ }^{7}$

Godaan dihadapi dengan pendidikan. Yang dapat mendidik adalah mereka yang mengalami keberhasilan maupun kegagalan. Pengalaman adalah guru jitu yang mengajarkan tentang hikmah kebijaksanaan. Belajar adalah kata kunci menuju keberhasilan. Dengan belajar, yang merupakan usaha untuk menguasai segala sesuatu yang berguna untuk hidup, terjadi perubahan dalam aspek fisiologis dan psikologis. ${ }^{16}$ Kekuatan, pemahaman, dan pengertian diharapkan semakin tumbuh. Terjadilah perubahan dari tidak tahu menjadi tahu, tidak mengerti menjadi mengerti, tidak dapat mengerjakan menjadi dapat mengerjakan, dan dari semula tidak paham menjadi paham.

Menikmati ASI adalah hak anak untuk mendapat kebutuhan dasar dan mencapai potensi optimal. ${ }^{14}$ Menyusui adalah hak ibu dan anak bersama tanpa intervensi. Kepentingan anak tersirat dan tersurat dalam perbuatan ibu. Ia mau berbuat untuk kepentingan anak, baik dalam waktu dekat maupun untuk waktu yang akan datang. Perilaku altruistis ditunjukkan ibu. Ia mengesampingkan diri demi kesejahteraan anak. Secara tradisional, hal ini adalah suatu kekuatan murni atau alami dari hati nurani, suatu keikhlasan tanpa pamrih untuk berbagi kasih, suatu bentuk naluri yang merespon kebutuhan mereka yang tergantung, terutama anak-anak.

Menyusui adalah proses yang tidak datang dengan sendirinya dan berjalan lancar sesuai kehendak. Suka dan duka menyertai proses ini. Stres fisik karena nyeri luka jalan lahir dan puting sering terjadi. Stres psikis juga terjadi karena kenyamanan rutinitas ibu terganggu. Memaksa dan menahan memerlukan kekuatan dan ketangguhan untuk melawan stres karena stres mempunyai kekuatan yang mendesak atau mencekam. ${ }^{16}$ Ibu mengantisipasi hal ini sehingga dapat mengatasi stres yaitu 
dengan sikap, keyakinan, serta pikiran positif yang bertujuan positif memberi penguatan. Kepentingan pribadi dikesampingkan agar langkah menuju tujuan tercapai. Menjadi ibu yang baik adalah sabar dalam merawat anak, memiliki tanggung jawab untuk merawat anak, mampu membagi waktu, serta memprioritaskan kebutuhan anak dari kebutuhan diri. ${ }^{17}$ Dengan konsep ini, egoisme diri ibu menjadi berkurang. Ia mendahulukan kebutuhan anak daripada kebutuhan diri dan ibu yang baik rela kehilangan waktu tidurnya demi memenuhi kepentingan bayinya. ${ }^{18}$ Ibu menerima kenyataan bahwa ada sesuatu yang membatasi kesenangan setelah diri menjadi ibu. Prioritas anak didahulukan sehingga ibu mengurangi waktu untuk kesenangan dan kepentingan pribadi.

\section{Tujuan}

Menyusui adalah proses bio-fisio-psikologis yang dilakukan dua manusia yang mempunyai tujuan untuk kepentingan bersama. Selain memenuhi kebutuhan biologis, ada tujuan untuk menghasilkan sesuatu yang efektif dan kepentingan yang lebih luas. Ada cita-cita yang mengarah ke luar, yaitu lingkungan kehidupan. Anak yang mendapat ASI mendapat kesempatan untuk tumbuh dan berkembang secara optimal sehingga ia berkualitas sebagai generasi penerus bangsa. ${ }^{19}$

Tujuan menyusui untuk ibu antara lain sebagai kontrasepsi alamiah, kebugaran, dan menurunkan kemungkinan keganasan. Kebanggaan dan hiburan ia nikmati. Jalinan kedekatan bertujuan untuk membentuk kepedulian dan sikap "tidak menyepelekan" anak terhadapnya. Kesadaran diri ibu semakin tumbuh dengan pengalaman menyusui, bukan hanya untuk kepentingan diri semata, tetapi juga untuk kepentingan hidupnya yang lebih luas. Ia semakin pandai dalam memaknai dan mengantisipasi kehidupan. Pandai bersikap adalah hasil dari pengalaman sekarang dan kondisi masa lalu serta adanya kesempatan berkreasi. ${ }^{13}$ Ia pandai menata, bukan hanya bagaimana jalan menuju tujuan, tetapi juga mengantisipasi kemungkinan sesuatu yang menjadi penghalang atau mengancam diri di kemudian hari. Untuk itu, dalam sikap yang matang terdapat proses yang terus-menerus untuk mengantisipasi kejadian di masa yang akan datang, menilai kembali realitas yang sekarang dialami, dan meregulasi harapan sehingga kesejahteraan terbina dalam roda kehidupan yang terus berputar.

Tujuan untuk anak adalah memberi asupan, kekebalan, keintiman, dan kecerdasan. Ibu berpendapat bahwa anak manusia seyogyanya diberi susu manusia. Komunikasi nonverbal melalui menyusui merupakan sarana ibu mengekspresikan pertolongan terhadap kebutuhan lahir batin anak. Ibu mengembangkan mental anak sejak dini dengan pemahaman bahwa untuk menyusui dibutuhkan pengertian dan perjuangan anak. Modal fundamental anak adalah pemahaman dan hasrat yang didapat melalui masukan dari persepsi dan perilaku. Anak memperoleh pengetahuan dari mengobservasi tindakan sendiri (menghisap, mengecap, dan menjangkau barang yang diamati). Dalam proses menyusui, anak mengobservasi dalam pikiran atau merasakan proses menghisap, tatapan mata, dan reaksi ibu, serta meraba tubuh ibu di sekitar payudara. Semua pengalaman masuk ke dalam benak anak dan menjadi modal pembentukan diri kelak. Perkembangan pengetahuan anak didapat dari beragam reaksi ibu dan respon-respon yang saling mereka berikan. ${ }^{20}$ Tujuan untuk ibu dan anak melalui proses menyusui antara lain belajar mencintai dan merasakan nikmatnya dicintai. ${ }^{19}$ Secara fisik, terjadi proses saling menguntungkan. Ibu menjadi lega setelah anak menyusu. Anak dikenyangkan serta ketegangan payudara dan pikiran ibu diturunkan. Antara mereka terjadi peran timbalbalik dalam saling merespon secara positif. Mereka berbagi kesenangan, memunculkan harmoni, saling peduli, saling percaya, dan saling mendekatkan diri. ${ }^{21}$ Kekuatan dan kebajikan antara mereka menjadi fondasi positif dalam relasi sepanjang hidup. ${ }^{2}$

\section{Kesejahteraan}

Kesejahteraan dibentuk oleh kejadian atau pengalaman dan sumber yang berpengaruh pada kemampuan individu meraih tujuan pribadinya. ${ }^{22}$ Dalam proses menyusui diduga bahwa aktivasi produksi opioid oleh hisapan pada puting mempromosikan afeksi positif pada perilaku yang berhubungan dengan menjadi seorang ibu. Kepedulian terhadap keberadaan dan keselamatan anak meningkat. Perilaku ini diduga dipengaruhi oleh hormon-hormon yang berhubungan dengan adanya imbalan positif. ${ }^{20}$ Ibu menunjukkan rasa bangga, puas, lega, rindu, dan cinta yang diutarakan dalam nyanyian, ungkapan, dan sentuhan bahagia. Afeksi positif terwujud sebagai perbuatan yang positif. Individu dengan afeksi positif pada umumnya menunjukkan pola pikir yang luas, fleksibel, kreatif, dan efisien. Afeksi positif berperan positif terhadap peningkatan kegiatan di otak dan regulasi fisiologi tubuh yang positif antara lain dalam memproduksi ASI.

Kebahagiaan dan kesehatan ibu dan anak memancar ke seluruh keluarga. Interelasi antara mereka menjadi lancar dan baik, beban perekonomian keluarga diperingan, serta rasa syukur mereka semakin tumbuh. Ibu menyusui berkontribusi besar pada kesejahteraan keluarga, lingkungan, dan bangsa. ${ }^{4}$

\section{Kesimpulan}

Pilihan menjadi ibu yang bertanggung jawab terhadap kebahagiaan dan keselamatan anak yang dilahirkan menyebabkan ibu sadar diri tentang keunggulan dan kekuatan spiritual ASI yang alami dan diberkahi Ilahi. Ia memaknai ASI dan mau menyusui. Dukungan moral dan 
tenaga dari suami, keluarga, dan media kesehatan membantu perjuangan ibu. Dengan demikian, tumbuhlah afeksi positif, sikap yang kuat, serta tujuan yang terarah menuju kesejahteraan. Kekuatan-kekuatan psikologis ini mendukung keberhasilan ibu menyusui lebih dari 6 bulan.

\section{Saran}

Sebagai manfaat dari penelitian ini, dengan menyadari kelemahannya, temuannya dapat dijadikan masukan bagi upaya promosi kesehatan terkait ASI eksklusif.

\section{Daftar Pustaka}

1. Afiyanti Y. Persepsi menjadi ibu yang baik. Jurnal Keperawatan Indonesia. 2003; 7 (2): 54-60.

2. Burnard P. Learning human skills, an experiential and reflective guide for nurses and health care professionals. England: Elsevier Science Ltd; 2002.

3. Collins NL, Feeney BC. A safe haven: an attachment theory perspective on support seeking and caregiving in intimate relationship. Journal of Personality and Social Psychology. 2000; 78 (6): 1053-73.

4. Ikatan Dokter Anak Indonesia. Air susu ibu dan tumbuh kembang anak; 2009 [cited 2010 April 01]. Available from: http://www.idai.or.id

5. Compton WC. Positive psychology. USA: Wadsworth; 2005.

6. Fikawati S, Syafiq A. Penyebab keberhasilan dan kegagalan praktik pemberian ASI eksklusif. Kesmas Jurnal Kesehatan Masyarakat Nasional. 2009; 4 (3): 120-31

7. Dhandapany G, Bethou A, Arunagirinathan A, Ananthakrisnan S. Antenatal counseling on breastfeeding. International Breastfeeding Journal. 2008; 3(5). Available from: http://www.internationalbreastfeedingjournal.com/content/3/1/5 .
8. Ramadani M, Hadi EN. Dukungan suami dalam pemberian ASI eksklusif di Wilayah Kerja Puskesmas Air Tawar Kota Padang Sumatera Barat. Kesmas Jurnal Kesehatan Masyarakat Nasional. 2010; 4 (6): 26974.

9. Diener E, Seligman M. Very Happy People. Journal of Psychology Science. 2002; 13: 81-4.

10. Dignam. Understanding intimacy as experienced by breastfeeding women. Health Care for Women International. 1995; 16 (5): 477-85.

11. Helda. Kebijakan peningkatan pemberian ASI eksklusif. Kesmas Jurnal Kesehatan Masyarakat Nasional. 2009; 3: 195-200.

12. Health Promotion. National breastfeeding awareness week; 2009 [cited 2010 Januari 17]. Available from: www.publichealth.hscni.net.

13. Huppert FA, Baylis N, Keverne B. The science of well-being. London: Oxford University Press; 2006.

14. Infact Canada. Breastfeeding; 2010 [cited 2010 April 20]. Available from: http://www.infactcanada.

15. Lupton D, Fenwick J. They've forgotten that I'm the mum: constructing and practicing motherhood in special care nurseries. Social Science \& Medicine. 2001; 53: 1011-21.

16. Manajemen Laktasi. Menuju persalinan aman dan bayi baru lahir sehat. 2nd ed. Indonesia: Perkumpulan Perinatologi; 2004.

17. Maramis WF. Perilaku dalam pelayanan kesehatan. Indonesia: Airlangga University Press; 2006.

18. Martin, D. Emotional quality management. Indonesia: Arga; 2001.

19. Nursing Times. Breastfeeding; 2010 [cited 2010 February 17]. Available from: http://www.historytoday.com.

20. Rempel LA. Factors influencing the breastfeeding decisions of long-term breastfeeders. J Human Lactation. 2004; 20: 306-17.

21. Ryan RM, Deci EL. On happiness and human potentials. Annual Reviews Psy. 2001; 52, 141-166.

22. Sunaryo. Psikologi untuk keperawatan. Jakarta: Buku Kedokteran EGC; 2004. 